УДК 82I.І6І.І

ББК $83.3(2 \mathrm{Poc}=\mathrm{Pyc}) 52$
О ТЯЖБЕ ПО ПОВОДУ «ТЯЖБЫ»

И ПРОБЛЕМАХ ДАТИРОВАНИЯ ХОРОШО ЗАПОМНИВШЕГОСЯ СОВРЕМЕННИКАМ ЭПИЗОДА БИОГРАФИИ ГОГОЛЯ

(C) 2017 г. Е.Г. Падерина

Институт мировой литературы им. А.М. Горького Российской академии наук, Москва, Россия

Дата поступления статьи: І8 января 2017 г. Дата публикации: 25 июня 2017 г.

DOI: I0.22455/2500-4247-20I7-2-2-290-3I5

Аннотация: Статья посвящена датировке окончательной редакции «Тяжбы» Гоголя, прочитанной автором в доме Аксаковых в первый приезд в Россию из-за границы (I839-I840). Авторское чтение сопровождалось своеобразной мистификацией: Гоголь не сообщил, что начинает читать пьесу, и «литературная» икота персонажа была воспринята слушателями как бытовая и гоголевская. Казус запомнился многим, но даты, указанные мемуаристами, расходятся. С.Т. Аксаков приводит 8 марта I840 г., а И.И. Панаев - лето І839 г. До сих пор эпизод не имеет точной датировки, комментаторы выдвигают разные предположения о том, кто из мемуаристов ошибся. Автор статьи кроме всех имеющихся биографических, эпистолярных и мемуарных данных привлекает к анализу мемуарного разночтения результаты текстологического исследования «Тяжбы» и типологического сравнения мемуаров Аксакова и Панаева (разные цели и жанровые установки - разный баланс между вымыслом и фактом). Аксаков составлял хронику общения с Гоголем, которую рано было печатать, Панаев писал для ближайших номеров «Современника» и заботился о занимательности своих мемуарных очерков. Анализ полного комплекса данных и аналитических результатов позволяет приурочить гоголевский розыгрыш, а значит, и саму редакцию пьесы - к марту I840 г.

ключевые слова: Гоголь, Аксаков, Панаев, комментарий, мемуарный жанр, беллетристика, датировка.

Информация об авторе: Екатерина Геннадьевна Падерина - доктор филологических наук, ведущий научный сотрудник, Институт мировой литературы им. А.М. Горького Российской академии наук, ул. Поварская, д. 25 а, І2Іо69 Москва, Россия.

E-mail: kbogan@yandex.ru 


\section{ON LITIGATION CONCERNING "LITIGATION": THE PROBLEMS OF DATING ONE EPISODE OF GOGOL'S BIOGRAPHY}

This is an open access article distributed under the Creative Commons Attribution 4.0 International (CC BY 4.0)
(C) 20I7. E.G. Paderina

A.M. Gorky Institute of World Literature of the Russian Academy of Sciences, Moscow, Russia Received: January $\mathrm{I} 8,2017$

Date of publication: June 25, 2017

Abstract: This article focuses on the problems around the exact dating of the final edition of Gogol's play The Letigation read aloud by the author in house of Aksakov on his first return to Russia from abroad (I839-I840). Gogol's reading is famous for a peculiar hoax: the author did not declare his intention to read the piece, so the listeners took hiccups of his fictional character for his own. Many remembered the incident but the notes of the memorialists on the date of the incident diverge. S.T. Aksakov mentions March 8, I840 and I.I. Panaev - Summer of I839. As the episode has not been hitherto dated, Gogol commentators put forward various conjectures about who of the memorialists made a mistake. Besides using all available biographical, epistolary, and memoir data for the analysis of this discrepancy, the author of the paper turns to the results of the textological research of Litigation and typological comparison of Aksakov's and Panaev's memoirs. Both had different goals and generic intentions and thereby we observe a different balance between facts and fiction in the memoirs of each. Aksakov made chronological records of his communication with Gogol that were too premature to publish. Panaev wrote for the upcoming issues of the journal Contemporary and was concerned with entertaining his audience. Analysis of the entire complex of existing data allows date Gogol's hoax and, consequently, the final edition of the play by March I84O.

Keywords: Gogol, Aksakov, Panaev, commentary, memoir genre, polite literature, dating.

Information about the author: Ekaterina G. Paderina, DSc in Philology, Leading Research Fellow, A.M. Gorky Institute of World Literature of the Russian Academy of Sciences, Povarskaya 25 a, I21069 Moscow, Russia.

E-mail: kbogan@yandex.ru. 
Авторское чтение «Тяжбы» запечатлелось в памяти мемуаристов из-за своеобразной мистификации слушателей. Пьеса открывается монологом сенатского секретаря Пролетова, просматривающего после сытного обеда «Северную пчелу» и постоянно икающего, и «литературная» икота Гоголя, не сообщившего о начале чтения, была со смущением воспринята присутствующими как бытовая. Казус случился дважды, как минимум, - в гостях у Аксаковых и у Чертковых - и оказался, на первый взгляд, хорошо документированным: он описан с указанием точной даты - С.Т. Аксаковым в мемуapax о Гоголе, с приблизительной - И. Панаевым в воспоминаниях, а также известен в записи П. Бартеневым устного рассказа дочери Е.Г. и А.Д. Чертковых - С.А. Ермоловой, запомнившей розыгрыш без названия пьесы и без даты. Но Аксаков и Панаев приурочили чтение к разному времени, и разница составляет почти полгода, в итоге хорошо запомнившийся современникам эпизод гоголевской биографии не имеет не только точной датировки, но и солидарной предположительной. При этом комментировался эпизод много раз - в изданиях, имеющих отношение к жизни и творчеству Гоголя, Аксакова, Панаева и В.Г. Белинского, и попытки вычислить наиболее вероятный ход событий привели к ряду отличных друг от друга предположительных выводов и сделанных в примечаниях к аксаковскому и панаевскому описаниям поправок в датах со ссылками на забывчивость того или другого мемуариста.

Комментирование «Тяжбы» в новейшем академическом издании Гоголя (ИМЛИ РАН), всколыхнув разнообразие высказываний, суждений и предположений по поводу гоголевского розыгрыша, в очередной раз поставило ту же задачу установления наиболее достоверной даты в пределах 
почти восьми месяцев пребывания Гоголя в России. Это важно совсем не только из-за примечательной мистификации слушателей (штриха в характере Гоголя и яркого эпизода в восприятии пьесы современниками). По уточненным текстологическим и палеографическим данным истории текста «Тяжбы» начало монолога икающего Пролетова было написано Гоголем не ранее его приезда в Москву в І839 г. и заменило прежний вариант начальной сцены (I836 г.) непосредственно перед первой авторской шуткой с размыванием границ бытового и литературного общения. А сама замена первой сцены является значимым пунктом в процессе формирования поэтики драматурга, завершившего к г839 г. (причем еще до отъезда из России в I836 г.) только две пьесы - драматические сцены «Утро делового человека» и полновесную классическую комедию «Ревизор».

Возвращение к подробностям своеобразной тяжбы комментаторов по поводу датировки розыгрыша подняло на поверхность и проблему доверия к мемуарам как традиционному источнику историко-литературных и биографических данных. В науке не раз возникал вопрос об относительной достоверности мемуарных сведений, «размытых» временной дистанцией и/или психологическими и пр. установками мемуаристов ${ }^{\text {. }}$ И в научных изданиях мемуаров даются сведения об истории их создания и более или менее подробная характеристика предпочтений мемуариста в отборе событий хроникального, эмоционально-психологического, идеологического, историко-культурного и т. п. рядов в качестве основы повествования. Однако при решении прикладных задач, для которых воспоминания современника лишь источник данных, жанрово-видовая характеристика конкретных мемуаров часто не учитывается. Между тем еще одной невольной тяжбой в истории с чтением «Тяжбы» можно назвать разнотипность воспоминаний о Гоголе и, в частности, об одном и том же, интересующем нас, розыгрыше С.Т. Аксакова и И.И. Панаева: принципиально отличаются цели, задачи, отношение к фактам и - отношение к Гоголю. Известно, что Аксаков не всегда и не во всем понимал Гоголя, но понимал ли его Панаев - не обсуждалось. Кто из них точнее передал реальные события - безмерно любивший Гоголя Аксаков или сторонний наблюдатель Панаев? Результаты нового «дознания» представлены в настоящей статье. 
Начнем с достоверных данных. I4 октября І839 г. Гоголь читал «Тяжбу» в доме С.Т. Аксакова, который сообщил об этом I7 октября сыновьям в Петербург: «Гоголь читал у нас начало комедии “Тяжба” и большую главу из романа (вероятно “Мертвые души”). И то и другое - чудные созданья! Особенно глава из романа! И к этому надо прибавить, что он так читает или, лучше, играет, как никто! Лучшие актеры, мне известные, пред ним ученики в театральном искусстве. Восхищение было всеобщее» [16, с. 566]. Этим, собственно, точные данные исчерпываются, а остальные обстоятельства реконструируются предположительно и с разной степенью вероятности. Поэтому важно подчеркнуть, что из письма Аксакова мы узнаем три факта: читалась «Тяжба», из нее прочитано было «начало», и в тот же день Гоголь прочел первую главу «Мертвых душ».

Решить по письму, разыграл ли Гоголь слушателей «Тяжбы» в этот день, нельзя, поскольку об этом не сказано ни слова, а упомянутое непревзойденное мастерство Гоголя-чтеца неизменно восхищало слушателей, что бы он ни читал - прозу или отрывки из пьес 2 .

По-видимому, о том же вечере в аксаковском доме, как единодушно признают все комментаторы, писали во второй половине октября г839 г. братьям в Петербург В.С. и К.С. Аксаковы, но, к сожалению, в самых общих выражениях. Так, Вера Сергеевна сообщила об октябрьском «субботнем» чтении: «В этот вечер Гоголь читал нам отрывок из своей комедии, и еще другой из какой-то повести, кажется “Мертвых душ”, жаль, что вас не было; все, что он читал, превосходно, чудно; к тому же он так читает, как никакой актер не сумеет сыграть» [16, с. 572]. Еще менее определенно выразился Константин Сергеевич: «Через несколько времени все уселись в гостиной, и Гоголь начал читать нам. - Я и все прерывали его часто хохотом. Все, что ни прочел он, есть истинно художественное произведение» [І6, с. 570]. Как мы видим, ни один из них не обмолвился о примечательном, мистифицирующем слушателей, «натуральном» вхождении в комедийный текст. К тому же, судя по описке Константина Сергеевича (упоминании об одном

\footnotetext{
2 Ср., напр., воспоминание Аксакова о чтении Гоголем «Женитьбы» в Москве в I835 г.: «Гоголь до того мастерски читал или, лучше сказать, играл свою пьесу, что многие, понимающие это дело люди, до сих пор говорят, что на сцене, несмотря на хорошую игру актеров, особенно господина Садовского в роли Подколесина, эта комедия не так полна, цельна и далеко не так смешна, как в чтении самого автора» [2, с. 93].
} 
произведении), в его восприятии чтение первой главы поэмы совершенно заслонило драматический отрывок³.

Розыгрыш Сергей Тимофеевич описал в мемуарах, но - под другой датой: «Восьмого марта, при многих гостях, совершенно неожиданно для нас, Гоголь объявил, что хочет читать. Разумеется, все пришли в восхищение от такого известия, и все соединились в гостиной. Гоголь сел за боковой круглый стол, вынул какую-то тетрадку, вдруг икнул и, опустив бумагу, сказал, как он объелся грибков. Это было начало комической сцены, которую он нам прочел. Он начал чтение до такой степени натурально, что ни один из присутствующих не догадался, что слышит сочинение. Впрочем, не только начало, но и вся сцена была точно также читана естественно и превосходно» (курсив автора. - Е.Г.) [2, с. 37].

Несовпадение эпистолярной и мемуарной даты чтения «Тяжбы» может быть следствием ошибки памяти Аксакова, как и решили многие комментаторы после выхода в свет в І952 г. 58-го тома «Литературного наследства» с фрагментами неизвестных прежде писем Аксаковых. Такая точка зрения превалирует до сих пор 4 , но оснований для уверенности в этом нет.

Прежде всего с большой долей вероятности можно предполагать, что Гоголь читал «Тяжбу» в аксаковском доме дважды. Впервые эту мысль высказал Ю.В. Манн [І8, с. 78]. Такого же мнения придерживалась Е.Н. Купреянова, обратившая внимание на то, что С.Т. Аксаков в октябрьском письме сыновьям в Петербург писал о «начале комедии», а в мемуарном описании гоголевского розыгрыша - о целиком прочитанной пьесе [I4, с. 3I].

К этому следует добавить, что в «Истории...» Аксакова, в отличие от его письма к сыновьям, мистификация слушателей «Тяжбы» не объединена с чтением той или иной главы «Мертвых душ» [2, с. 37]. Между тем само это сочетание наверняка закрепилось бы в живых и прочных ассоциациях (в отличие от даты, с которой, действительно, память могла не справиться в точности). Тем более что первые месяцы I840 г. описываются Аксаковым в связи с поступательным знакомством с поэмой, а при этом - с определен-

\footnotetext{
3 Об этом говорит и то, что в письме за приведенной нами выше оценкой услышанного следует вывод, явно относящийся именно к «Мертвым душам»: «Гоголь - великий, гениальный художник, имеющий полное право стоять, как и Пушкин, в кругу первых поэтов, Гете, Шекспира, Шиллера и проч.» [16, с. 570].

4 См., в частности, перекрестные отсылки комментатора к I4 октября I839 г. как дате розыгрыша в новейшем издании [8, т. 2, с. $758,789,809]$.
} 
ной неуверенностью в датах: «Так шло время до возвращения Ольги Семеновны с Верой и с Соничкой Самборской из Обояни. Они воротились, кажется, 2-го или 3-го февраля, вероятно, в субботу, потому что у нас обедал Гоголь и много гостей. Достоверно, что во время их отсутствия, продолжавшегося ровно месяц, Гоголь нам ничего не читал; но когда начал он читать нам “Мертвые души”, то есть которого именно числа, письменных доказательств нет. Легко может быть, что он читал один или два раза по возвращении нашем из Петербурга, от 23-го декабря до 2-го января, потому что в письмах Веры к Машеньке Карташевской есть известие, от І4-го февраля, что мы слушали уже итальянскую его повесть (“Анунциату”) и что 6-го марта Гоголь прочел нам уже четвертую главу “Мертвых душ” [2, с. 37]. Далее следует уже приведенное нами выше описание розыгрыша под датой 8 марта, после которого Аксаков продолжил: «После этого, в одну из суббот, он прочел пятую главу, а г7-го апреля, тоже в субботу, он прочел нам, перед самой заутреней светлого воскресенья, в маленьком моем кабинете, шестую главу, в которой создание Плюшкина привело меня и всех нас в великий восторг» [2, с. 37].

Уместно между тем задаться вопросом, отчего первое по приезде в Россию гоголевское чтение было так прочно забыто старшим Аксаковым? Знакомство с началом поэмы могло, на наш взгляд, заслониться последующим поступательным движением впечатлений от главы к главе, тем более что именно дальнейшее погружение в повествование (в отличие от первоначальных «вероятно “Мертвые души” С.Т. Аксакова и «какой-то повести, кажется “Мертвых душ”» В.С. Аксаковой в октябрьских письмах) открыло Аксаковым особую глубину и значительность этого произведения. При этом сам розыгрыш с монологом Пролетова Аксаков запомнил хорошо; так хорошо, что пользуясь при составлении своей хроники документами домашнего архива, в частности подготовленной Верой Сергеевной копией всяких упоминаний о Гоголе из своих писем к М.Г. Карташевской ${ }^{5}$ надиктовал эпизод с мистификацией непосредственно по памяти или, не исключено, по каким-то своим заметкам, потому что в упомянутой рукописи с выписками о розыгрыше нет ни слова. На старших детей гоголевская шутка, судя по документам, такого сильного впечатления, как на отца, не произвела, но во 
время подготовки с их активной помощью рукописи «Истории моего знакомства с Гоголем» дети вполне могли этот розыгрыш вспомнить и в том числе при необходимости скорректировать отцовскую память, однако этого не произошло.

Теперь стоит посмотреть на ту же дилемму (осенью или весной случился интересующий нас эпизод) со стороны самого автора. По нашему мнению, вероятность того, что с монолога икающего Пролетова Гоголь начал первое же по возвращении из-за границы чтение своих произведений в России, чрезвычайно мала. В частности, маловероятно, что он предварил таким розыгрышем чтение первой главы «Мертвых душ», т. е. первое знакомство соотечественников с результатами без малого четырехлетних усилий по воплощению самого «близшего сердцу» (по его выражению) замысла.

Сама по себе мысль начать первое чтение с чего-нибудь не столь значительного, как «Мертвые души», и именно с драматического фрагмента логично объясняется желанием автора подготовить аудиторию к восприятию повествования, в котором продумано и важно каждое слово. В этом плане первая редакция (г836) начала «Тяжбы», для нас утраченная, совершенно подходила для этого уже потому, что была существенно длиннее, как свидетельствуют палеографические и текстологические данные, и, видимо, выдержана в более традиционных формах. А вот шутка с размыванием границ между бытовой и литературной речью в начале «Тяжбы» могла привести (и скорее всего - привела бы) к противоположному результату. «Физиологическое» (или «натуральное», по выражению Аксакова) начало чтения, смутившее хозяев дома, гостей могло просто эпатировать, сформировав негативные ожидания перед чтением поэмы. Гоголь не мог не помнить о том, как принималась «Женитьба» в авторском чтении в Москве в мае І835 г. («Слушатели до того смеялись, что некоторым сделалось почти дурно; но, увы, комедия не была понята! Большая часть говорила, что пьеса неестественный фарс, но что Гоголь ужасно смешно читает» [2, с. I4]); задели его, как известно, за живое и упреки в грубой фарсовости, посыпавшиеся после премьеры «Ревизора» в I836 г. Словом, вряд ли он перед «Мертвыми душами» рискнул бы «оскорбить вкус» части присутствующих, со многими из которых он не был знаком вообще или коротко и, соответственно, не знал, какой реакции ожидать. 
В этом плане идеальная обстановка для шутки с литературной икотой была в гостях у Чертковых. Память их дочери не сохранила ни названия, ни жанровой принадлежности услышанного, но в точности запечатлела атмосферу вечера. П.И. Бартенев с ее слов записал следующее: «У Чертковых он (Гоголь. - Е.Г.) держал себя откровенно и добродушно. Софья Александровна помнит, как однажды он начал икать и говорил: “чорт возьми, как я у вас объелся, напала икота”, и далее разный вздор. “Да перестаньте же”, - говорят ему. “Что же вы мне мешаете”, - отвечает Гоголь. Оказалось, что это было началом его какой-то повести» [6, с. 30I]. Никак не помогая в точной датировке розыгрыша (чтение в доме Чертковых могло произойти и до, и после поездки Гоголя вместе с Аксаковыми в Петербург, т. е. осенью или зимой I839 г., а также ранней весной I840 г.), это воспоминание, однако, указывает на важный эмоционально-психологический фон: известен установившийся шутливый тон общения Гоголя с хозяйкойб ${ }^{6}$ и ясно из воспоминаний дочери, что не было «посторонних» (в отличие от обеда у Аксаковых), что позволяло Гоголю «опробовать» реакцию слушающих.

Достоин внимания и сам прием - родом из интермедий, для которых характерна диффузия сценического и реального («театрального», по терминологии П. Богатырева) диалога. Впервые Гоголь использовал подобный прием при переделке «Женихов» в «Женитьбу», первые черновые наброски которой в «Самаринской тетради» открываются монологом Подколесина, лежащего на диване в халате и задающегося вопросом, а не пора ли жениться наконец (с такого же вопроса, заданного самому себе Гарлекином, начинается известная интермедия «Гаерская свадьба», под другим названием - «Свадьба Гарлекина»). Близкий, по всей видимости, этим пер-

6 С Е.Г. Чертковой Гоголь провел в мае I839 г. в Риме долгие часы у постели умирающего Иосифа Виельгорского; перед ее отъездом из Рима он сделал в ее альбоме шуточную запись с намеками на ее пристрастие к нюхательному табаку: «Наша дружба священна. Она началась на дне тавлинки. Там встретились наши носы и почувствовали братское расположение друг к другу, несмотря на видимое несходство характеров» и далее. См. полностью: [9, т. IX, c. 25-26]. Не менее шутливое письмо он написал ей 22 июня I839 г. из Вены; ср. начало: «Странная вещь. Как только напьюсь чаю, в ту же минуту кто-то невидимый толкает меня под руку писать к вам, и Елисавет<а> Григорьевна не сходит ни на минуту с мыслей» [9, т. VIII, c. 236].

7 «Я все думаю [что] на щот того, что естл<и?> <... [мерой] пришлось так, что нужно женит<ся><..> все ж таки служишь. Надворный советник!» (ОР РГБ. Ф. 74. К. 6. Ед. хр. 3. Л. 29; купюры в данном случае обозначают утраты текста вследствие повреждения рукописи). 
вым наброскам текст монолога Подколесина и читался Гоголем на рубеже марта-апреля I835 г. в Петербурге Погодину, а потом в мае того же года в Москве в погодинском доме. Легко представить вероятное смущение слушателей, если бы Гоголь и в этом случае не обозначил начала литературного текста. Со стороны комедиографической поэтики сходство тоже представляет интерес. Известное начало «Тяжбы» с икотой Пролетова образует тот же сценический эффект, что и начало «Женитьбы»: с поднятием занавеса зритель застает главного героя в момент обнажения потаенных намерений и, что называется, «в неглиже». Но в «Тяжбе» прием усилен контрастом между обстановкой (служебный кабинет) и физиологическими подробностями послеобеденного состояния.

Сугубо устный и театральный характер ныне известного начального монолога в «Тяжбе», с актуальными петербургскими реалиями и с русским просторечием, граничащим с площадной фразиологией (ср.: «Надоела мне эта “Северная Пчела”. Точь-в-точь баба, засидевшаяся в девках»), вряд ли мог родиться не только за границей, но и в тиши кабинета в доме Погодина, у которого Гоголь остановился по приезде в Москву. В течение двух недель до первого чтения его внимание было, по-видимому, целиком сконцентрировано на «Мертвых душах»; не исключено, впрочем, и то, что он так или иначе занимался «Тяжбой», но вероятность этого незначительна (совершенно другой драматический сюжет занимал его мысли в I839 г. - трагедия из истории Запорожья). Существенно при этом, что серьезное сокращение прежнего зачина «Тяжбы» и заведомая ориентация нового на зрительный зал предполагают те или иные побудительные мотивы такой переделки, и таковыми могли стать - наблюдаемая автором непосредственная реакция аудитории (в частности, Щепкина) во время чтения первой редакции начала I4 октября и/или впечатления от театральной публики на спектакле «Ревизора», состоявшемся г7 октября.

Наконец, следует учесть и то, что в окончательной редакции начальный монолог не только короче прежней экспозиции, но и слишком короток, чтобы составить прочитанное «начало» (по выражению старшего Аксакова в письме сыновьям) или «отрывок из своей комедии» (по формулировке Веры Сергеевны): буквально следом за монологом Пролетова, возмущенного награждением Бурдюкова, на сцене появляется другой Бурдюков и начинает свой рассказ про козни брата и про завещание тетки, подписавшейся 
вместо имени Евдокия словом «обмокни», а после ухода помещика-степняка следует завершающий пьесу веский, но еще более короткий монолог Пролетова, раскрывающий суть его характера и планов. По сути, цельность окончательной редакции драматического отрывка такова, что в нем фактически нет паузы, на которой можно было бы оборвать чтение. И это тоже заставляет самым серьезным образом сомневаться в популярной у комментаторов версии об октябрьской датировке гоголевского розыгрыша. Возможный аргумент, что короткий и цельный «драматический отрывок» мог быть воспринят Аксаковым, а тем паче его дочерью как фрагмент пьесы большего объема, не серьезен, поскольку театральный опыт старшего Аксакова (в г82о-е гг. один из лучших театральных критиков и цензор), в том числе опыт участия в спектаклях так называемого домашнего театра, ориентированного на интермедийные традиции, а также опыт читателя пушкинских «драматических сцен» и гоголевской («Утро делового человека», I836) исключают такую ошибку в его восприятии.

Что же сообщил Панаев? В его воспоминаниях гоголевский розыгрыш описан именно в сочетании с чтением первой главы «Мертвых душ» (как в письме С.Т. Аксакова) и отнесен к I839 г. Правда, Панаев указал на лето того года, в то время как Гоголь вместе с Погодиным приехали в Москву только 26 сентября, но это небольшое смещение легко, как кажется, исправляется на I4 октября (когда Панаев был в Москве), что и сделали комментаторы аксаковской «Истории...», изданной в серии «Литературных памятников» (I960). Указанная Аксаковым-мемуаристом дата 8 марта І840 г. была признана ими ошибкой памяти именно с привлечением, кроме многократно упомянутых нами писем Аксаковых, - «свидетельства» Панаева [2, с. 257].

То, что известно из биографии Панаева о времени, в течение которого Гоголь был в России, как будто подтверждает принятое комментаторами решение, получившее впоследствии, как уже говорилось, вид научной традиции. Летом г839 г. Панаев вместе с А.Я. Панаевой останавливался в Москве проездом в Казань, где был занят вступлением в наследство. А вернулся он из Казани с женой и двоюродным братом (В.А. Панаевым) не позднее го октября. Константин Аксаков в письме к братьям упоминает Панаева среди гостей той октябрьской субботы, когда Гоголь читал «Тяжбу» [ı6, с. 570].

Напомним панаевское описание розыгрыша. 
Гоголь встал с дивана, взглянув на меня не совсем приятным и пытливым глазом (он не любил, как я узнал после, присутствия мало знакомых ему лиц при его чтениях) и направил шаги в гостиную. Все последовали за ним. В гостиной дамы уже давно ожидали его.

Он нехотя подошел к большому овальному столу перед диваном, сел на диван, бросил беглый взгляд на всех, опять начал уверять, что он не знает, что прочесть, что у него нет ничего обделанного и оконченного... и вдруг икнул раз, другой, третий...

Дамы переглянулись между собою, мы не смели обнаружить при этом никакого движения и только смотрели на него в тупом недоумении.

- Что это у меня? точно отрыжка? - сказал Гоголь и остановился. Хозяин и хозяйка дома даже несколько смутились... Им, вероятно, пришло в голову, что обед их не понравился Гоголю, что он расстроил желудок...

Гоголь продолжал:

- Вчерашний обед засел в горле, эти грибки да ботвиньи! Ешь, ешь, просто чорт знает, чего не ешь...

И заикал снова, вынув рукопись из заднего кармана и кладя ее перед собою... «Прочитать еще “Северную пчелу”, что там такое?..» - говорил он, уже следя глазами свою рукопись.

Тут только мы догадались, что эта икота и эти слова были началом чтения драматического отрывка, напечатанного впоследствии под именем «Тяжбы». Лица всех озарились смехом, но громко смеяться никто не смел... Все только посматривали друг на друга, как бы говоря: «Каково? каково читает?» Щепкин заморгал глазами, полными слез.

Чтение отрывка продолжалось не более получаса. Восторг был всеобщий; он подействовал на автора.

- Теперь я вам прочту, - сказал он, - первую главу моих «Мертвых душ», хоть она еще не обделана... [22, с. 30-31].

На первый взгляд эпизод выглядит весьма правдоподобно (отличие от аксаковского письма только в том, что в версии Панаева прочитана была вся пьеса), и нет ничего удивительного в том, что он показался комментаторам достоверным свидетельством (в более ранних научных публикациях с исправлением даты на март I840 г. [20, с. I9I; 21, с. 393; 7, с. 62I], в более поздних - с признанием г839 г. и исправлением только числа [2, с. 257; 8, 
т. 3, с. 287]). Но уже второй взгляд на рассказ Панаева рождает массу вопросов и сомнений в его достоверности.

То, что ретроспективное описание Панаевым эпизода конца I830-х соответствует позднейшей модели «уверенный в своем величии гений среди обожающих его поклонников», вроде бы легко корректируется. Но под этот «образ» Гоголя Панаев «подогнал» и событийный контекст той осени. В результате предшествующие розыгрышу события в его подаче явно относятся к числу сугубо фантазийных. Так, в авторитетных изданиях сборников «свидетельств» современников о Гоголе извлеченный из панаевских воспоминаний сегмент I839 г. открывается следующим «фактом»:

Перед отъездом нашим Михайло Семеныч объявил мне, что он на днях будет обедать у Сергея Тимофеича с Гоголем (который только что приехал в Москву), и с таинственным тоном прибавил умиленным и дрожавшим голосом:

- Ведь он, кажется, намерен прочесть там что-то новенькое!..

Действительно, через несколько дней после этого Сергей Тимофеич пригласил меня обедать, сказав, что у него будет Гоголь и что он обещал прочесть первую главу «Мертвых душ» $[7$, с. 2І2; 8, т. 3, с. 282].

Начнем с того, что ясно из полного мемуарного текста: это был «отъезд» Панаева и Белинского из Химок - с дачи Щепкина, который - по всем данным - не покидал Москву после появления в ней Гоголя ${ }^{8}$. Очень вероятно, однако, что актер привечал друзей еще летом до отъезда Панаева в Казань, тогда это все то же наложение летних и осенних впечатлений мемуариста. Можно объяснить и «таинственное» сообщение Щепкина о приезде Гоголя, в реальности просившего актера никому об этом не говорить. Но приглашения Щепкина к Аксаковым на чтение «чего-то новенького», а тем

8 Например, В.А. Панаев (двоюродный брат мемуариста), приехавший осенью г839 г. из Казани вместе с молодой четой, вспоминал: «Во время пребывания моего в Москве, раза два Иван Иванович возил меня обедать к Аксаковым. <...> В числе посторонних лиц, обедавших у Аксакова, были тогда - Белинский, Щепкин и Загоскин» [5, № 9, с. 473].

9 Сохранилась записка актера от 28 сентября г839 г., отправленная к Аксаковым в деревню, где упоминание о гоголевской просьбе «никому не сказывать, что он здесь» соседствует с признанием: «Не утерпел, чтобы не известить вас о таком для нас сюрпризе» [19, с. I77]. 
более приглашения Панаева на обед по случаю того, что Гоголь «обещал прочесть первую главу “Мертвых душ” - быть, разумеется, не могло. Как известно, двери аксаковского дома были открыты Гоголю в любое время, и он бывал у них после 2 октября «почти каждый день и очень часто обедал» [2, с. 20; 8, т. 2, с. 672], но вопросы о привезенных произведениях «всегда ему были очень неприятны», и «он особенно любил держать в секрете то, чем он занимался» [2, с. 19; 8, т. 2, с. 671]. И «хотя слух о “Мертвых душах” обежал уже всю Россию» [2, с. 20], в письме Константина Сергеевича братьям, написанном в двадцатых числах октября І839 г., прямо указывается на полную неожиданность давно и терпеливо ожидаемого чтения, состоявшегося в вечер I4 октября [16, с. 570]. Напомним и о неуверенности эпистолярного сообщения С.Т. Аксакова по поводу того, что кроме начала «Тяжбы» была прочитана глава из «романа», «вероятно из “Мертвых душ”».

Очевидно, что дело не в частых ошибках Панаева в датах, отмечаемых комментаторами [2I, с. 392; 7, с. 621; 4, с. 635-638]. Перед нами типичный литературный анекдот, набросанный легким пером и, повторяем, с фантазией. А дальнейшее развертывание сюжета «из памяти» Панаева напоминает даже о тридцати пяти тысячах курьеров.

«В исходе четвертого прибыл Гоголь... Он встретился со мною, как с старым знакомым, и сказал, пожав мне руку:

- А, и вы здесь... Каким образом?» [7, с. 212; 8, т. 3, с. 282]. В наиболее смелых предположениях Панаев был представлен Гоголю впервые 2 октября [8, т. 3, с. 287], т. е. только что, а в более осторожных - в ноябре того года в Петербурге [7, с. 623]. Далее следуют хорошо узнаваемые читателями I860-х гг. ${ }^{\mathrm{I0}}$ и, по-видимому, позднейшими комментаторами «типичные» черты гоголевского образа: любовь к макаронам, реальный или притворный сон как способ уйти от назойливого общения, благоговейное и робкое отношение к Гоголю всего аксаковского семейства. Всему этому есть соответствия и в воспоминаниях Аксакова, только относятся они к другому времени и другим встречам. В число узнаваемых деталей входит и то, что «об обещанном чтении Гоголь перед обедом не говорил ни слова» [7, с. 2І2; 8, т. 3, с. 283], только к осени І839 г. это не имеет отношения, поскольку «обещаний» Гоголь тогда еще не давал. И категорически не соответствует

Iо Панаев писал свои воспоминания для публикации в «Современнике», и они печатались порционно в течение і86г г. 
характеру хозяина дома и его отношению к Гоголю в тот период [2, с. 20] (и все последующие) описание реакции старшего Аксакова на отказ Гоголя от якобы данного «обещания»:

Все томились от этой неизвестности, и Сергей Тимофеич первый решился вывести всех из такого неприятного положения.

- А вы, кажется, Николай Васильич, дали нам обещание?.. вы не забыли его? - спросил он осторожно...

Гоголя подернуло несколько.

- Какое обещание?.. Ах, да! Но я сегодня, право, не имею расположения к чтению и буду читать дурно, вы меня лучше уж избавьте от этого...

При этих словах мы все приуныли; но Сергей Тимофеич не потерял духа и с большою тонкостию и ловкостию стал упрашивать его... Гоголь отговаривался более получаса, переменяя беспрестанно разговор. Потом потянулся и сказал:

- Ну, так и быть, я, пожалуй, что-нибудь прочту вам... Не знаю только, что прочесть?.. - И приподнялся с дивана [22, с. 22].

Этот результат литературной обработки, по сути, подгонка под вышеупомянутую канву эпизода с гением среди обожателей (Гоголь вынуждает упрашивать себя, и кто-то должен эту роль исполнить). В конце I830-х это не было приметой гоголевского общения с друзьями, но к І86о-м гг. воспринималось читателями как узнаваемая и типичная черта.

Надо сказать, что гоголевская часть «Литературных воспоминаний» писалась Панаевым еще позднее аксаковской «Истории...» - в I86I гг., и память, разумеется, его подводила. Но дело в другом. Его мемуары носят в целом и в частностях, относящихся к Гоголю, явно беллетризованный характер, вполне соответствующий названию ${ }^{\mathrm{II}}$ и задачам журнальной публикации. Панаев не только невольно спутал даты и частично совместил впечатления разного времени, но и определенно приукрасил рассказывае-

\footnotetext{
II Связь понятия «литературные воспоминания» с выборкой мемуаристом событий, имеющих отношение к литературному процессу, приобрела устойчивость позднее; в заголовочный комплекс, сколько нам известно, до Панаева такое словосочетание не включалось, так что стилизационный характер панаевских мемуаров позволяет предполагать долю авторской шутки. Во всяком случае, посвященные Белинскому и опубликованные годом ранее мемуары озаглавлены «Воспоминания о Белинском».
} 
мое - для большей занимательности, видимо, но в большей степени потому, что свою задачу видел в верной характерологии, в психологической точности обрисовки портретов замечательных деятелей той эпохи. Открытым, однако, остается вопрос, как хорошо он эти характеры понимал и насколько точно трактовал поведение этих людей, зачастую интересовавших читателей больше, чем мемуариста.

На наш взгляд, он вовсе не склонен был врать, а просто воспринимал жизнь, в том числе свою, со стороны ее типичности и соответствовал этому в любом своем рассказе (не только литературном, но буквально бытовом, в письмах, например [26; 29]). От природы наблюдательный, он легко подмечал в людях и событиях разные характерные черты, только конфигурации этих черт были известны ему заранее из тех или иных авторитетных для него источников (из литературы, под влиянием идейных убеждений «соратников» ${ }^{12}$ и т. п.). На отношение Панаева к Гоголю в I839 г. сильное влияние имело восхищение Гоголем Белинского, но священного трепета, в котором признается мемуарист, конечно, не было ${ }^{\mathrm{r}}$. Хотя в I839 г. «имя Гоголя уже начинало греметь» [5, № 9, с. 469-470], сам И.И. Панаев все еще был увлечен Кукольником ${ }^{\mathrm{I4}}$, в «больших талантах» которого он пытался убедить своего дядю, А.И. Панаева, в Казани [5, № 9, с. 470]. Отношение к Гоголю Панаева-мемуариста соответствовало убеждению Белинского в «переломе» гоголевского творчества и, так сказать, в порче таланта проповедничеством. Но, рисуя близкими к гротесковым красками «благоговейное» отношение к писателю аксаковской семьи, т. е. позднейшую типичную картинку, Панаев со свойственной ему самоиронией включил и себя в число обожателей, соблюдя таким образом правдоподобие.

\footnotetext{
I2 О его несамостоятельности в мыслях и суждениях писал, напр., И.С. Тургенев в воспоминаниях о Белинском (ср.: «...человек добродушный, но крайне легкомысленный, способный схватывать одни лишь верхи верхушек» [4, с. 49I]; верность этой черты (при всех позднейших полемических наслоениях в мемуарах Тургенева) подтверждается эпистолярными отзывами о характере Панаева только знакомых или близко его знавших, включая Белинского [15, с. г33, г36].

I3 Ср. двусмысленную оценку Гоголя в письме к Белинскому от І6 июля г838 г. - «этот гигант текущей литературной минуты» [26, с. 513].

I4 Хотя в г86о-м Панаев признается в увлечении Кукольником в молодости, а все-таки посмеивается над неадекватной оценкой бывшим кумиром «Ревизора» в I836 г., смешивая впечатления разных времен [24, с. 435-436; 8, т. 3, с. 278-279].
} 
В целом, в отличие от аксаковских мемуаров, написанных, так сказать, вообще литературным слогом, «литературный» характер панаевских «воспоминаний» заключается в том, что это литература, инкрустированная отдельными воспоминаниями, не всегда своими. И жанровая ориентация соответствует наиболее удававшемуся ему вектору - литературного фельетона. В одном из таких печатных высказываний «Нового поэта» в I855 г. (№ 6 «Современника») Панаев посмеивался над спекулятивным отношением журналистов к имени Гоголя и над публикациями самых разных воспоминаний «с его незначительным словом, произнесенным когда-то и где-то, или с трехстрочной запиской, вымоленной у кого-то из его приятелей» [8, т. 3, с. 274]. Вольно или невольно в этой позиции он фактически оказался последователем С.Т. Аксакова, уже в I853 г. призвавшего не спекулировать на гоголевском имени и тем более не торопиться с обнародованием не вполне корректных, не проверенных и т. п. псевдосвидетельств [г, с. 360-36г; см. то же: 8, т. 2, с. 627-629]. Но если Аксакова это побудило к собственной ответственности и последовательной осторожности утверждений, то Панаева, напротив, - к иронии и даже гоголевской, в своем роде, смешливости в отношении к фактам. «Если бы я вздумал идти за так называемыми собирателями материалов для биографии Гоголя, если бы я захотел похвастать перед моими читателями моим знакомством с ним, - я мог бы напечатать и мои воспоминания о нем. В этих воспоминаниях я, конечно, уже не позволил бы себе увлекаться фантазией», - написал в упомянутом фельетоне Панаев и тут же привел свой красочный и детализированный рассказ о встрече Гоголя с «молодыми литераторами», включающий и произнесенное Гоголем по тому или иному поводу [8, т. 3 , c. 274-275]. А следом за этой стилизацией мемуарного жанра, в которой трудно отделить реальные события от типизации, он со смехом заключает: «Из этого отрывка, заимствованного из моих воспоминаний о Гоголе, биографы его могут, по крайней мере, вывести заключение, что Гоголь любил малагу, а из иных воспоминаний об нем не выжмешь даже и такого факта» [8, т. 3, с. 275].

В г839 г. К.С. Аксаков, несмотря на дружеские отношения с Панаевым, в одном из разговоров с отцом назвал его Хлестаковым [I5, с. I34], и с этим сравнением мы вполне солидарны не только по части легкости в мыслях, но в отношении совершенного добродушия Ивана Ивановича, с такой 
же легкостью соглашавшегося признать «ошибки памяти» в случае упреков в передергивании фактов ${ }^{15}$.

В таком фантазийном контексте подробности, которыми оснащено панаевское описание чтения «Тяжбы», конечно, не вызывают доверия. Тем более что начальный монолог Пролетова мемуарист процитировал по изданию «Сочинений Гоголя» (I842 или I855 г.), оснастив ремарками о поведении читающего и реакции слушателей [22, с. 3I].

Итак, опереться на воспоминания Панаева как «свидетельство» нельзя. Мы совершенно согласны с оценкой С.С. Машинского, считавшего, что С.Т. Аксаков более точен «в изложении фактов» [7, с. 62I]. Но исправить ошибочную дату («лето г839 г.») на 8 марта І840 г., как сделали редакторы полного и выборочного издания «Литературных мемуаров» ${ }^{16}$, тоже, к сожалению, нельзя. Дело в том, что сохранилось письмо И.И. Панаева к К.С. Аксакову от 2 марта г840 г. из Петербурга, свидетельствующее о том, что в Москву мемуарист в эти дни даже не собирался [29, с. 2І3]. Никаких намеков на поездку весной І840 г. в Москву нет и в других данных о его биографии. Следовательно, ни 8 марта г 840 г., ни в близком времени (если С.Т. Аксаков ошибся числом), Панаева в Москве не было.

Вернемся к осени г839 г., которая описана также и в воспоминаниях жены и двоюродного брата Панаева - без упоминаний о чтении. Оба были радушно приняты в аксаковском доме, но на интересующем нас обеде их, разумеется, могло и не быть, однако странно, что нет упоминаний о впечатлениях Панаева от встречи с Гоголем. Авдотья Яковлевна и сама в пору написания воспоминаний была опытной беллетристкой, так же мало, как и ее

I5 Так, в конце г86г г., по напечатаии в «Современнике» последних глав «Литературных воспоминаний», в московской газете «Русская речь» появилась заметка (за подписью «Т) с упреками в искажении человеческого облика Грановского передергиванием слов, ситуаций, сопровождением всего «игривым слогом» повествователя и, наконец, просто враньем, в частности, по поводу оценки Грановским «Семейной хроники и воспоминаний» С.Т. Аксакова: «...спрашивается: как мог Грановский, скончавшийся в 55 г., говорить о книге, вышедшей в 56, да еще через два года после ее появления? Желательно, чтоб г. Панаев объяснил нам такой странный факт, и это ему вероятно будет легко потому, что он так ясно помнит все подробности вечера у Арапетова» (курсив в оригинале. - Е.П.) [I7, с. 67I]. На что Панаев ответил, хотя и в третьем лице (включив ответ в «Заметки Нового поэта»), в последнем за г86г г. номере «Современника», приведя полную цитату обвинения во лжи (включая саркастический пассаж, процитированный выше), добродушно поблагодарил за «справедливое замечание» и извинился за «непростительный недосмотр» [25, с. 249-250]. I6 И. Ямпольский [2I, с. 392] и С. Машинский [7, с. 621]. 
первый муж, заботившейся о фактической или «исторической» точности ${ }^{17}$. Будучи осенью I839 г. семнадцатилетней девушкой строгого воспитания из петербургской актерской семьи, она вряд ли адекватно понимала происходящее и тем более вряд ли могла бы, как представлено в ее мемуарной версии, воспринять поведение Гоголя как капризы гения. А вот брат, В.А. Панаев, хотя и тоже юный, со вниманием прислушивался к литературным обсуждениям в Казани и Москве [5, № 9, с. 469-470]; при этом литературной деятельностью в период составления воспоминаний (инженер не только по профессии, но и по характеру мысли) не занимался и относился к прошедшему сообразно традиционным представлениям о мемуарном жанре.

Примечательно, что при полном, повторяем, отсутствии в воспоминаниях жены и брата Панаева упоминаний о гоголевском чтении в этих разных по типу - повествованиях о былом есть один совпадающий эпизод, который примыкает к эпизоду с «Тяжбой» по воле случая, так что его непреднамеренный характер позволяет довериться сообщению.

В Казань (точнее, в близлежащее село Нармонка) Панаев поехал для оформления наследства, составлявшего часть имения деда по отцовской линии - А.В. Страхова. В деле на равных правах участвовало несколько родственников. И жена с братом в подробностях описали казусный дележ наследства, при котором не судебная, но тяжба за справедливый раздел имущества к концу второго месяца привела к тому, что «резали, рвали и разбивали пополам все, что только могло подлежать такому дележу», а серебряную посуду рубили топором [5, № 8, с. 339; 28, с. І21]. Совершенно очевидно, что именно гоголевская «Тяжба», будь она услышана И.И. Панаевым целиком, в любой редакции - с розыгрышем или без, давала ему, любившему анекдотическую сторону жизни светскому остроумцу, серьезный повод к тому или иному упоминанию ее в разговоре с родными в связи с житейским семейным анекдотом. Но - нет.

Между тем Панаев тоже не оставил без внимания перипетии наследственного раздела и к концу г839 г. написал небольшую повесть «Раздел имения», напечатав ее во втором номере «Отечественных записок» за I840 г. «Закорючки», пользуясь пушкинским выражением о гоголевском «Владимире...», в повести нет ни по поводу наследства, ни в рамках цен-

I7 Коррективы сочиненных ею обстоятельств гоголевской жизни вносил уже

В.И. Шенрок [8, т. 3, с. 290-291]. 
тральной фабульной линии - истории женитьбы повествователя на милейшей молодой вдове, которую после нескольких идиллических месяцев он застал с другим. Обстоятельства раздела имущества, наблюдаемые повествователем «по случаю», стали фабульным поводом знакомства с будущей избранницей - не похожей на других наследников, влюбленности и женитьбы. Детали раздела, известные по мемуарам жены и брата, мелькают по ходу рассказа, поданные с добродушной иронией, - никаких ассоциаций и намеков на гоголевский гротескный сюжет. А ведь в целом беллетристика Панаева при тематическом пересечении с гоголевскими сюжетами не лишена вольных и/или невольных аллюзий к ним ${ }^{18}$.

Надо сказать, что о Гоголе октябрьской осени I839 г. сохранился еще один отзыв, в котором тоже можно было бы предполагать отголоски впечатлений от розыгрыша с «Тяжбой», но их там нет. Н.Ф. Павлов писал в Баварию С.П. Шевыреву $з$ октября того года о московских новостях, в том числе подробно об известном инциденте с вызовом автора «Ревизора»во время спектакля I7 октября. Не очень понятно из писем Аксаковых, был ли Павлов у них в тот именно вечер, когда Гоголь в первый раз читал (сам Павлов весьма лаконичен: «Гоголь здесь, и он немножко гримасничает» [3о, c. 557]), но на следующем, близком по времени, вечере с Гоголем - точно был, причем одновременно с Панаевым и Белинским; об этом упоминает в письме к братьям К.С. Аксаков [І6, с. 570]. По впечатлениям Константина Сергеевича, Павлов чувствовал себя рядом с Гоголем не в своей тарелке («жалок и смешон и не знает, какую роль принять ему в присутствии Гоголя, который его давит и подавляет» [16, с. 570]), и тем больше оснований он имел съязвить в письме к Шевыреву по поводу гоголевской мистификации, о которой непременно узнал бы от Панаева ${ }^{\text {I9 }}$, от Сергея Тимофеевича или от М.С. Щепкина, если бы она случилась.

I8 Например, определенное влияние гоголевской сцены «Лакейская» усматривается в одном из очерков И.И. Панаева, печатавшихся под псевдонимом «Нового поэта», «Петербургская прислуга (Лакей из хороших домов)», где лакейская спесь нанятого повествователем слуги, почерпнутая в барских домах, раскрывается в разговоре с горничной [23].

I9 Любитель житейских и литературных анекдотов, Панаев невольно тут же выплескивал их в общении, совершенно не задумываясь о последствиях; так, Вера Сергеевна писала брату Ивану в конце І84I г. о Гоголе и в том числе о гоголевской просьбе не распространяться о нем: «Но только ты, милый Ванечка, пожалуйста, не сообщай ничего никому, ни товарищам, ни Панаеву - из этого более выходят сплетни» [16, с. 61о]. 
К предположительному смещению панаевских впечатлений от розыгрыша на позднюю осень, когда Гоголь и Аксаковы были в Петербурге, тоже нет оснований: это отразилось бы в упомянутой повести или в письмах того времени, по которым известно, кстати, что с Гоголем Панаев (и Белинский) виделись у Одоевского, а не у Аксаковых [І5, с. І35]. В итоге создается впечатление, что эпизод с гоголевским розыгрышем запомнился Панаеву с чужих слов, и такая вероятность не исключена (среди устных рассказов о гоголевских шутках и чудачествах, особенно распространившихся по смерти писателя, вполне мог бытовать и этот эпизод).

Остается еще раз вернуться к мемуарному описанию С.Т. Аксакова. Подчеркнем, что он не полагался на свою память, работая над рукописью воспоминаний. Сообщая 28 марта I852 г. А.О. Смирновой о том, что 2I февраля начал писать и диктовать «о Гоголе», вначале без плана, а потом «Историю знакомства и переписки с Гоголем», он писал: «Всего труднее сохранить хронологический порядок до начала постоянной переписки, т. е. до I840 года» [Iо, с. I52]. Но именно поэтому он готовил (по большей части диктовал) свои воспоминания по собственным заметкам и данным семейного архива (на письма дочери и старшего сына он сам постоянно ссылается и как на источник сведений, и оправдывая отсутствие точных данных $)^{20}$. Иван Сергеевич в І850-е гг. много времени проводил вдали от дома и вряд ли участвовал в подготовке отцовских воспоминаний, но в последующем именно он готовил рукопись к печати и в том числе корректировал отдельные детали и подробности [8, т. 2, с. 674-68I], имея под руками и отцовские письма, адресованные ему и Григорию. Но, опять же, дата эпизода с розыгрышем его не смутила. Достойна внимания еще одна подробность истории подготовки аксаковских мемуаров: первая, краткая, редакция воспоминаний была составлена для П. Кулиша, только что взявшегося за биографический труд о Гоголе. И, судя по адресованному Кулишу письму от го июня I954 г., поначалу старший Аксаков помнил лишь, что «по возвращении» в

20 Первый издатель полной рукописи С.Т. Аксакова, Н.М. Павлов, перечислил подготовленные и частично использованные мемуаристом документы, и кроме разных писем там значатся «выписки из дневника старшей дочери» и «выдержки из ее переписки с М.Г. Карташевской», а также «заметки и черновые наброски, частью продиктованные и лишь переправленные, а частью писанные от начала до конца собственноручно Сергеем Тимофеевичем - очевидно назначавшиеся сюда же» [2, с. II7]; о рукописи В.С. Аксаковой см. также: [8, т. 2. с. $644^{-645]}$. 
Россию Гоголь, помимо «Мертвых душ», «читал также отрывки из комедии “Тяжба” [Із, с. 253; 8, т. 2, с. 637]. Почему позднее, уточняя даты и подробности по письмам детей, он не запросил у Ивана Сергеевича своих писем, не вполне ясно, как и то, из какого источника он почерпнул подробности розыгрыша, не упоминавшегося, как мы уже говорили, в выписках из писем дочери.

Так или иначе, поставив дату розыгрыша 8 марта I840 г., он мог, разумеется, допустить ошибку, но, как мы уверены в итоге, только в числе. И.А. Виноградов обратил внимание на то, что в выписках Веры Сергеевны следующая за записью от 8 марта І840 г. выписка не датирована, она просто начинается с абзаца, но явно отсылает ко дню рождения Константина, т. е. к 29 марта: «В пятницу Гоголь у нас опять читал, но не из “Мертвых душ”, а из какой-то комедии. Мы уже думали, что он уже никогда более не будет читать, потому что слышали, что это ему уже наскучило, и, конечно, он это сделал по особенному случаю» ${ }^{21}$. Из этого комментатор сделал вывод, что С.Т. Аксаков датировал розыгрыш, «ошибочно следуя» пропуску даты в рукописном сборнике, а чтение состоялось «на самом деле несколькими месяцами ранее - I4 октября I839 г.» [8, т. 2, с. 809]. Очень вероятно, между тем, что мемуарист имел в виду именно день рождения сына, и очень вероятно, что Гоголь приурочил свою шутку именно к этому дню, чтобы повеселить, кроме прочего, Константина и его гостей. Словом, допустить, что недатированная Верою запись спровоцировала ошибку в дне, можно и даже нужно. Но это допущение (и только) способно переместить впечатления от гоголевской мистификации только на несколько дней, но никак - на несколько месяцев.

В итоге все данные так или иначе указывают на то, что при невозможности указать точную дату розыгрыша с началом «Тяжбы», в целом следует отнести его к марту I840 г., а в соответствии с этим датировать и подготовку Гоголем нового начала пьесы, т. е. монолога икающего Пролетова. 


\section{Список литературы}

$<$ Аксаков С.T.> С. A-в. Несколько слов о биографии Гоголя // Московские ведомости. І853. 21 марта. № 35. С. 360-36г.

Аксаков С.Т. История моего знакомства с Гоголем / подгот. текста и примеч.

Е.П. Населенко и Е.А. Смирновой. М.: Изд. АН СССР, г96о [Сер. «Литературные памятники»]. 294 с.

3 Берков П.Н. Проблемы исторического развития литератур. Статьи. Л.: Худож. лит., г98г. 495 с.

В.Г. Белинский в воспоминаниях современников. М.: Худож. лит., І977. 733 с. Воспоминания В.А. Панаева // Русская Старина. І893. № 8. С. 320-355; № 9. C. 46I-502.

Воспоминания С.А. Ермоловой о Гоголе. Из записной книжки «Русского Архива» // Русский Архив. г909. Кн. 6. С. 301.

Гоголь в воспоминаниях современников / Ред. текста, предисл. и комм. С.И. Машинского. М.: Гос. изд-во худож. лит., І952. 718 с.

Гоголь в воспоминаниях, дневниках, переписке современников. Полный систематический свод документальных свидетельств: в 3 т. / Изд. подготовил И.А. Виноградов. М.: ИМЛИ РАН, 2ОІ2-20I3. Т. 2-3. І032 с. + II68 с.

9 Гоголь Н.В. Полное собрание сочинений: в І4 т. <Б. м.>: Изд-во АН СССР, І937-І952.

Iо Из переписки А.О. Смирновой с Аксаковыми // Русский Архив. І896. Кн. I. С. I42-I60. История моего знакомства с Гоголем со включением всей переписки с I842 по I852 год. Сочинение С.Т. Аксакова / под ред. Н.М. Павлова. М.: Тип. М.Г. Волчанинова, I89o. IV. 246 с.

Кошелев А.В. Пушкин в воспоминаниях: проблемы изучения литературных мемуаров: дис. ... д-ра филол. наук. Великий Новгород, 2011. 399 с. $<$ Кулиш П.> Записки о жизни Николая Васильевича Гоголя, составленные из воспоминаний его друзей и знакомых и из его собственных писем: в 2 т. СПб.: В тип. Александра Якобсона, І856. Т. І. 340 с.

I4 Купреянова Е.Н. Гоголь-комедиограф (публикация В.Е. Ветловской) // Русская литература. І990. № I. С. 6-33.

I5 Литературное наследство. М.: Изд-во АН СССР, І950. Т. 56: В.Г. Белинский. Кн. II. 625 c.

I6 Литературное наследство. М.: Изд-во АН СССР, І952. Т. 58: Пушкин. Лермонтов. Гоголь. го59 с.

I7 Литературные воспоминания г. Панаева. Грановский и Московский кружок. Современник № X // Русская речь и Московский вестник. І86г. № 94. 23 ноября. Отд. «Смесь». С. 669-671.

I8 Манн Ю.В. В поисках живой души: «Мертвые души». Писатель - критика - читатель. М.: Книга, І984. 35 с с. 
I9 Михаил Семенович Щепкин: Жизнь и творчество: в 2 т. М.: Искусство, I984. Т. I. 43I c.

20 Н.В. Гоголь в письмах и воспоминаниях / сост. В. Гиипиус. М.: Федерация, г93І. 496 c.

2 I Панаев И.И. Литературные воспоминания / ред. текста, вступ. ст. и примеч. И. Ямпольского. М.; Л.: Гос. Изд-во худож. лит., І950. 472 с.

22 Панаев И.И. Литературные воспоминания // Современник. г86г. № 9.

23 Панаев И.И. Очерки из петербургской жизни Нового поэта. Ч. I-2. СПб.: Тип. К. Вульфа, І86о. Ч. 2. С. 39-46.

24 Панаев И.И. Петербургская жизнь. Заметки Нового Поэта // Современник. І86о. № 4. С. $43 \mathrm{I}-464$.

25 Панаев И.И. Петербургская жизнь. Заметки Нового Поэта // Современник. І86г. № 12. С. $249-25$ O.

26 Панаев И.И. Письма // Панаев И.И. Сочинения. Л.: Худож. лит., І987. С. 5II-543.

27 Панаев И.И. Раздел имения (Из записок помещика) // Отечественные записки. I840. Т. VIII. № 2. Отд. III. Словесность. С. І58-г9о.

28 Панаева А.Я. Воспоминания. І824-І870. Изд. 4-е / под ред. и с прим. Корнея Чуковского. М.; Л.: Academia, I933. 582 с.

29 Письма И.И. Панаева к К.С. Аксакову // А.С. Пушкин. А.Н. Островский. Западники и славянофилы. Труды Всесоюзной Биб-ки им. В.И. Ленина. М.: Соцэкгиз, I939. Сб. IV.

30 Письма Н.Ф. Павлова к С.П. Шевыреву // Русский Архив. І897. № 4. С. 556-578.

3I Тартаковский А.Г. І8І2 год и русская мемуаристика. Опыт источниковедческого изучения. М.: Наука, І980. 312 с.

32 Тартаковский А.Г. Русская мемуаристика и историческое сознание XIX века. М.: Археогр. центр, І997. 356 с.

\section{References}

I <Aksakov S.T.> S. A-v. Neskol'ko slov o biografii Gogolia [Some words about the biography of Gogol]. Moskovskie vedomosti, I853, march 21, no 35, pp. 360-36I. (In Russ.)

2 Aksakov S.T. Istoriia moego znakomstva s Gogolem [The story of my acquaintance with Gogol], ed. and comment. by E.P. Naselenko and E.A. Smirnova. Moscow, AN SSSR Publ., I960 [Series Literary Monuments]. 294 p. (In Russ.)

3 Berkov P.N. Problemy istoricheskogo razvitiia literatur. Stat'i [Problems of the historical development of literatures. Articles]. Leningrad, Khudozh. lit. Publ., I98I. 495 p. (In Russ.)

4 V.G. Belinskii v vospominaniiakh sovremennikov [V.G. Belinsky in the memoirs of his contemporaries]. Moscow, Khudozh. lit. Publ., I977. 733 p. (In Russ.) 
Vospominaniia V.A. Panaeva [V.A. Panayev`s Memories]. Russkaia Starina, I893, no 8, pp. 320-355; no 9, pp. 46I-502. (In Russ.)

[Memoirs of S.A. Ermolova about Gogol. From the notebook of the "Russian Archive"]. Russkii Arkhiv, I909, book 6, p. 30I. (In Russ.)

Gogol'v vospominaniiakh sovremennikov [Gogol in the memoirs of his contemporaries], ed., intro. and comment. by S.I. Mashinsky. Moscow, Gos. izd-vo khudozh. lit. Publ., I952. 7I8 p. (In Russ.)

Gogol' v vospominaniiakh, dnevnikakh, perepiske sovremennikov. Polnyi sistematicheskii svod dokumental'nykh svidetel'stv: $v 3 t$. [Gogol in memoirs, diaries, and correspondence of his contemporaries. A complete and systematic set of documentary evidence: in 3 vol.], ed. I.A. Vinogradov. Moscow, IMLI RAN Publ., 20I2-20I3. Vol. 2-3. IO32 p. + II68 p. (In Russ.)

Gogol' N.V. Polnoe sobranie sochinenii: $v$ I4 t. [Complete works: in I4 vol.]. Izd-vo AN SSSR Publ., I937-I952. (In Russ.)

Iz perepiski A.O. Smirnovoi s Aksakovymi [From the correspondence of A.O. Smirnova with Aksakov]. Russkii Arkhiv, I896, book I, pp. I42-I6o. (In Russ.) Istoriia moego znakomstva s Gogolem so vkliucheniem vsei perepiski s I842 po I852 god. Sochinenie S.T. Aksakova [The story of my acquaintance with Gogol with the inclusion of all correspondence from I842 to I852. A Work By S.T. Aksakov], ed. N.M. Pavlova. Moscow, tip. M.G. Volchaninova Publ., I89o. IV, 246 p. (In Russ.) Koshelev A.V. Pushkin v vospominaniiakh: problemy izucheniia literaturnykh memuarov: diss. ... doctora. filol. nauk [Pushkin in the memoirs: problems in the study of literary memoirs. Diss. thesis]. Veliky Novgorod, 20II. 399 p. (In Russ.)

$<$ Kulish P.> Zapiski o zhizni Nikolaia Vasil'evicha Gogolia, sostavlennye iz vospominanii ego druzei $i$ znakomykh $i$ iz ego sobstvennykh pisem: $v 2 t$. [Notes on the life of Nikolai Gogol, composed of the memories of his friends and acquaintances, and from his own letters: in 2 vol.]. St. Petersburg, Tip. Aleksandra Iakobsona Publ., I856. Vol. I. 340 p. (In Russ.) Kupreianova E.N. Gogol'-komediograf (publikatsiia V.E. Vetlovskoi) [Gogol Comedy (publication by V.E. Vetlovskaya)]. Russkaia literatura, I990, no I, pp. 6-33. (In Russ.) Literaturnoe nasledstvo [Literary legacy]. Moscow, Izd. AN SSSR Publ., I950. T. 56: V.G. Belinskii. Kn. II [Vol. 56. V.G. Belinsky. Book. II]. 625 p. (In Russ.) Literaturnoe nasledstvo [Literary legacy]. Moscow, Izd. AN SSSR Publ., I952. T. 58: Pushkin. Lermontov. Gogol' [Vol. 58: Pushkin. Lermontov. Gogol]. I059 p. (In Russ.) Literaturnye vospominaniia g. Panaeva. Granovskii i Moskovskii kruzhok. Sovremennik № X [Panaev`s literary memoirs. Granovsky and Moscow circle. Contemporary No X]. Russkaia rech' i Moskovskii vestnik, I86I, no 94, 23 november, pp. 669-67I. (In Russ.) Mann Iu.V. V poiskakh zhivoi dushi: "Mertvye dushi". Pisatel' - kritika - chitatel' [In search of living soul: The Dead Souls. Writer - critic - reader]. Moscow, Kniga Publ., I984. 35I p. (In Russ.) 
Mikhail Semenovich Shchepkin: Zhizn' i tvorchestvo: $v 2 t$. [Mikhail Semyonovich Shchepkin: Life and works: in 2 vol.]. Moscow, Iskusstvo Publ., I984. Vol. I. 43I p. (In Russ.) N.V. Gogol'v pis'makh i vospominaniiakh [N.V. Gogol in letters and memoirs], ed. V. Gippius. Moscow, Federatsiia Publ., I931. 496 p. (In Russ.) Panaev I.I. Literaturnye vospominaniia [Literary memoirs], ed., intro. and notes by I. Iampol'sky. [Moscow, Leningrad], Gos. Izd-vo khudozh. lit. Publ., I950. 472 p. (In Russ.)

22 Panaev I.I. Literaturnye vospominaniia [Literary memoirs]. Sovremennik, I86I, no 9. (In Russ.)

23 Panaev I.I. Ocherki iz peterburgskoi zhizni Novogo poeta [Essays about the life of the New Poet]. Saint-Petersburg, tip. K. Vul'fa Publ., I86o, part 2, pp. 39-46. (In Russ.)

24 Panaev I.I. Peterburgskaia zhizn'. Zametki Novogo Poeta [Life in St. Petersburg. Notes of the New Poet]. Sovremennik, i86o, no 4, pp. 43I-464. (In Russ.)

25 Panaev I.I. Peterburgskaia zhizn'. Zametki Novogo Poeta [Life in St. Petersburg. Notes of the New Poet]. Sovremennik, I86I, no I2, pp. 249-250. (In Russ.)

26 Panaev I.I. Pis'ma [Letters]. Panaev I.I. Sochineniia [Panaev I.I. Works]. Leningrad, Khudozh. lit. Publ., I987, pp. 5II-543. (In Russ.)

27 Panaev I.I. Razdel imeniia (Iz zapisok pomeshchika) [Partition of the estate (From the notes of the landowner)]. Otechestvennye zapiski, I840, vol. VIII, no 2, otd. III Slovesnost', pp. I58-i9o. (In Russ.)

28 Panaeva A.Ia. Vospominaniia. I824-I870. Izd. 4-e [Memoirs. I824-I870. Ed. $4^{\text {th }}$, ed. and comment. by Korney Chukovsky. Moscow; Leningrad, Academia Publ., I 933. 582 p. (In Russ.)

29 Pis'ma I.I. Panaeva k K.S. Aksakovu [Letters from I.I. Panayev to C.S. Aksakov]. A.S. Pushkin. A.N. Ostrovskii. Zapadniki i slavianofily. Trudy Vsesoiuznoi Bib-ki im. V.I. Lenina. Sb. IV [A.S. Pushkin. A.N. Ostrovsky. Westerners and Slavophiles. Works of V.I. Lenin Library. Vol. IV]. Moscow, Sotsekgiz Publ., I939. (In Russ.)

30 Pis'ma N.F. Pavlova k S.P. Shevyrevu [Letters from N.F. Pavlov to S.P. Shevyrev]. Russkii Arkhiv, I897, no 4, pp. 556-578. (In Russ.)

3I Tartakovskii A.G. I8I2 god i russkaia memuaristika. Opyt istochnikovedcheskogo izucheniia [The year I8I2 and the Russian memoir genre. Source study]. Moscow, Nauka Publ., I980. 312 p. (In Russ.)

32 Tartakovskii A.G. Russkaia memuaristika i istoricheskoe soznanie XIX veka [Russian memoirs and historical consciousness of the $19^{\text {th }}$ century]. Moscow, Arkheogr. tsentr Publ., I997. 356 p. (In Russ.) 